\title{
Regional planning towards water resources analysis in the Argolis region
}

\author{
Evangelos Baltas ${ }^{1,}$, Elissavet Feloni ${ }^{1}$, George Bariamis ${ }^{1}$
}

\begin{abstract}
This research work aims at estimating the water balance regime as an aspect of the integrated management of surface and groundwater resources in Argolis in Greece, while the region's economy is strictly connected with the availability of fresh water. The analysis concerning the water supply estimation - both for the current period and for future projections taking into account climate change scenarios (HadCM2) - was held using a monthly water balance model. The assessment of water resources potential led to the necessity of adoption management practices and some suggestions are presented, including a multicriteria analysis for the re-planning of the region's station network.
\end{abstract}

Keywords-water balance model, climate change, multicriteria analysis, station network, water resources management

\section{Introduction}

Water is a natural resource of direct interest to the entire population, as well as to most ministries of development at central and state levels, municipalities, private sector and nongovernmental organizations (Biswas, 2004). Water resources adequacy is the main factor of development and, for this reason, the integrated management planning should take into account a number of criteria, such as the sustainability, the environmental requirements and the water quality standards (Gleick, 1998). Argolis is located in the Southern Greece and it is part of the regional unit of Peloponnese. The total area of the Region is $2154 \mathrm{~km}^{2}$. The greatest part of activities is related to agricultural and tourist sector and it is landed in Argolikos plain (Fig.1).

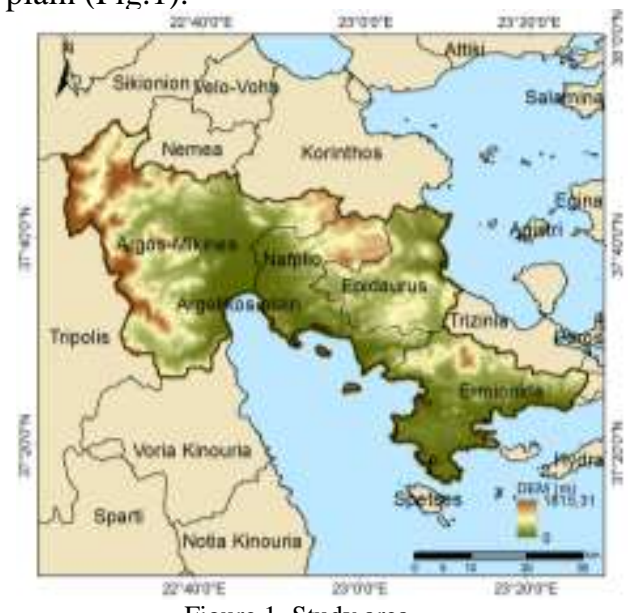

Figure 1. Study area

${ }^{1}$ Department of Water Resources and Environmental Engineering, School of Civil Engineering, National Technical University of Athens

5 Iroon Polytechniou, 157 80, Zografou, Attiki, Greece
In the plain and coastal areas annual rainfall varies from $400 \mathrm{~mm}$ to $600 \mathrm{~mm}$ while in the mountainous areas there is an increase in total precipitation depth which ranges between 800 $\mathrm{mm}$ and $900 \mathrm{~mm}$. The main surface water bodies are recorded in Tab.1. The area is under spot and diffuse pressures from waste waters that outpour into the natural water systems from the agricultural sector, industries and tourism services. The main asset that provides water for all the above uses are the groundwater bodies; however the discharge of the local springs tends to a slight or larger decrease. The reason why Argolis has suffered such water shortage has been subject for research and some of them are (i) the intense citrus and olive trees cultivation (Papageorgiou, 2007), combined with extended use of agrochemicals which results to nitrates pollution, (ii) the overpumping of groundwater, which led to a decrease in the groundwater head, the increase in both the energy costs and salinity levels. Empirical and misuse of irrigational water contributed to the vicious circle of over pumping. Fig.2a depicts the results of an artificial nourishment program which was held between 1985 and 1996. An additional reason is (iii) the extended use of agrochemical contributed decisively to the pollution of surface and groundwater bodies. Fig.2b shows the impact of this kind of pollution in the groundwater bodies.

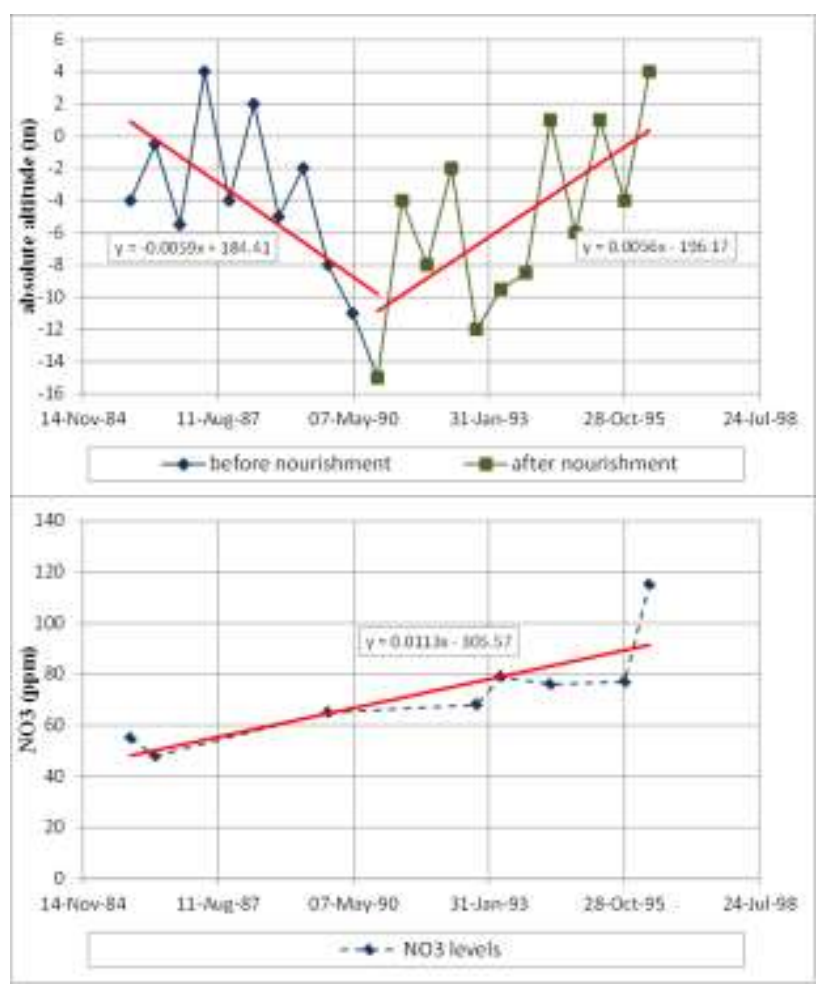

Figure 2. (a) Artificial nourishment (b) $\mathrm{NO}_{3}$ pollution 
Proc. of the Fourth International Conference on Advances in Civil, Structural and Environmental Engineering - ACSEE 2016. Copyright $(\odot$ Institute of Research Engineers and Doctors. All rights reserved.

ISBN: 978-1-63248-114-6 doi: 10.15224/ 978-1-63248-114-6-65

TABLE 1. ARGOLIKOS PLAIN MAIN SURFACE WATER BODIES

\begin{tabular}{|l|c|c|}
\hline \multicolumn{1}{|c|}{ Name } & $\begin{array}{c}\text { Length of main watercourse } \\
(\mathbf{k m})\end{array}$ & $\begin{array}{c}\text { River basin area } \\
\left(\mathbf{k m}^{\mathbf{2}}\right)\end{array}$ \\
\hline Inahos river & 41.69 & 537.48 \\
\hline Dafnon creek & 12.85 & 386.18 \\
\hline Tanos river & 43.07 & 260.19 \\
\hline Mariorea creek & 41.22 & 256.57 \\
\hline Vrasiatis creek & 17.32 & 251.12 \\
\hline Rhados river & 25.17 & 191.07 \\
\hline Xovrio creek & 26.68 & 172.49 \\
\hline
\end{tabular}

The investigation of any practical methods, which can improve the water resources management in Argolis, is of great importance, as the water availability is a priority for the further development in the region. Local economy is based on the tourism and agriculture. It has been estimated that irrigation water consumption reaches $92 \%$ of the total demand (about 92-110 $\mathrm{hm}^{3} \mathrm{year}^{-1}$ ), a much higher rate than the national average. Only the $15 \%$ of the irrigation needs are covered by the collective irrigation networks, while the remaining $85 \%$ corresponds to groundwater pumping (boreholes and wells). Annual water needs for both the resident population and visitors are about $7.47 \mathrm{hm}^{3} \mathrm{year}^{-1}$. The estimated population of the region in 2056 is 74600 inhabitants, an increase of $2.31 \%$ compared to 2011 (last national census). Given the planned tourism development (according to the Special Spatial Plan Tourism), tourism activity is expected to double in the next 40 years. With $15 \%$ uncertainty, $9.27 \mathrm{hm}^{3}$ year $^{-1}$ of fresh water will be required for the complete coverage of water supply needs. The industrial use of water is considered as constant $\left(4.5 \mathrm{hm}^{3} \mathrm{year}^{-1}\right)$. Also, water need for stock raising is not expected to appear further increase, but - for safety reasons the current amount of $1.6 \mathrm{hm}^{3}$ year ${ }^{-1}$ was considered as 2.0 $\mathrm{hm}^{3}$ year $^{-1}$. Consequently, the total annual amount of water needs is equal to $15.8 \mathrm{hm}^{3}$, disregarding irrigation water. The water balance simulation was held using sophisticated evapotranspiration, surface runoff and groundwater recharge models. The assessment of the available water resources in the future (target year 2056) was done taking into account the scenario HadCM2, using a downscaling method for the estimation of the monthly temperature and precipitation trends in the region. Results concerning surface and groundwater runoff reveal decreasing trends and this feature should be taken into account for an alteration in both water management strategies and water exploitation methods, while the inadequacy in historical hydrometeorological data demonstrated the necessity of planning an optimum station network, covering the entire region according to geomorphological, technical and administrative criteria. This approach is presented in the last section of the paper, along with the comparison between the suggested and the current heterogeneous station network.

\section{Methodology}

\section{A. Monthly water balance model}

The model used is an easy, fast and reliable monthly water balance model. It has been developed in the Laboratory of Hydrology and Water Resources Management (School of
Civil Engineering, National Technical University of Athens) in 1991 (Mimikou et al., 1991; Mimikou et al., 2000). It differs mainly in the method of potential evapotranspiration method, in some subroutines and in the calculation of the surface and groundwater discharge. The flow chart of the model as well as the necessary input data of precipitation, temperature, sunshine, relative humidity, wind speed and astronomical day duration are presented in Fig.3.

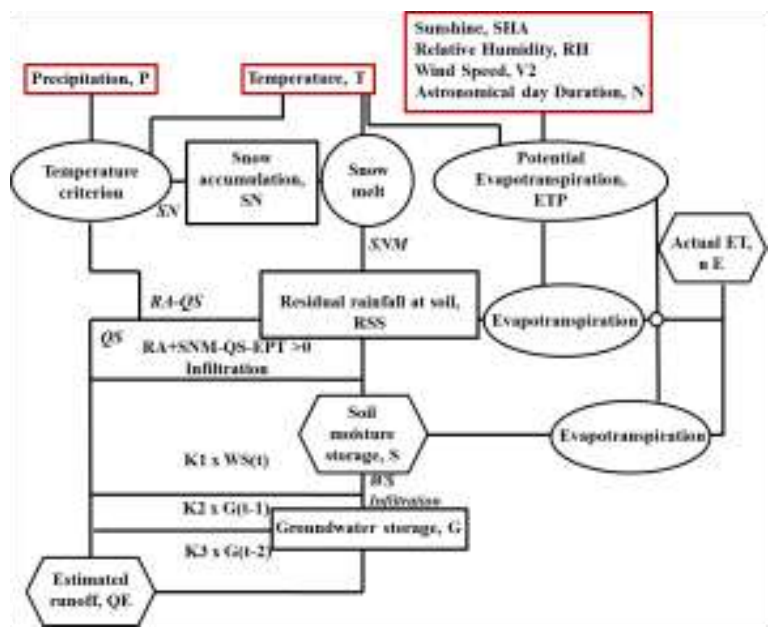

Figure 3. Flowchat of the water balance model

During the calibration process, the NTD index (Nash, 1970) was used (Eq.1).

$$
N T D=1-\frac{\sum_{i=1}^{k}\left(Q_{o b s_{i}}-Q_{c a l_{i}}\right)^{2}}{\sum_{i=1}^{k}\left(Q_{o b s_{i}}-\bar{Q}_{o b s}\right)^{2}}
$$

Where, $\mathrm{Q}_{\text {cal }}$ is the estimated runoff (according to the model), $\mathrm{Q}_{o b s}$ is the measured one, $\bar{Q}_{o b s}$ is the average measured runoff and NTD is the Nash Coefficient. NTD represents the ratio of the residual variance to the variance of the observed streamflows. Its value is 1 when the simulated streamflows are identical to the observed streamflows. As the difference between the calculated and observed streamflows increases, the coefficient decreases and can even become negative (Singh, 2002). Tab.1 depicts the values of the calibrated parameters of the model for each month.

\section{TABLE 2. MODEL PARAMETERS VALUES}

\begin{tabular}{|c|c|c|c|c|}
\hline Parameter & \multicolumn{2}{|c|}{ Value } & Parameter & Value \\
\hline \multirow{12}{*}{ SRC } & Oct & 0.12 & Smax & $195 \mathrm{~mm}$ \\
\hline & Nov & 0.14 & $\mathrm{~T}_{0}$ & $0.0 \mathrm{C}^{\circ}$ \\
\hline & Dec & 0.16 & $\mathrm{~T}_{1}$ & $2.8 \mathrm{C}^{\circ}$ \\
\hline & Jan & 0.18 & A & $20 \%$ \\
\hline & Feb & 0.20 & DF & $0.5 \mathrm{~mm} \cdot$ degrees/day \\
\hline & Mar & 0.18 & $\mathrm{~K}_{1}$ & 0.35 \\
\hline & Apr & 0.16 & $\mathrm{~K}_{2}$ & 0.35 \\
\hline & May & 0.12 & $\mathrm{~K}_{3}$ & 0.03 \\
\hline & Jun & 0.10 & & \\
\hline & Jul & 0.08 & & \\
\hline & Aug & 0.09 & & \\
\hline & Sep & 0.10 & & \\
\hline
\end{tabular}


Proc. of the Fourth International Conference on Advances in Civil, Structural and Environmental Engineering - ACSEE 2016. Copyright $\odot$ Institute of Research Engineers and Doctors. All rights reserved.

ISBN: 978-1-63248-114-6 doi: 10.15224/ 978-1-63248-114-6-65

After the calibration of the model, and with the purpose of estimating the runoff trends using different climatic scenarios, 50 timeseries of precipitation and temperature were produced using the appropriate stochastic model. The suitability of the model was tested using both the Portmanteau and Anderson test. According to them, the first-order moving average $M A(1)$ model was estimated as the best for the monthly precipitation timeseries, while the second-order autoregressive model $A R(2)$ for temperature. It is noted that the statistical characteristics of precipitation and temperature are based on 40-years climatology.

With the aim of determining the climate change impact on the water supply, the mean monthly change in precipitation and temperature was estimated, according to the HadCM2 Climate Scenario Data (Tab.2).

TABLE 3. MEAN MONTHLY TRENDS IN TEMPERATURE AND PRECIPITATION UP TO 2056 (HadCM2)

\begin{tabular}{|c|c|c|}
\hline Month & Temperature $\left({ }^{\circ} \mathbf{C}\right)$ & Precipitation (\%) \\
\hline Oct & 2.30 & -11.12 \\
\hline Nov & 1.89 & 3.55 \\
\hline Dec & 1.25 & -6.73 \\
\hline Jan & 0.83 & -8.96 \\
\hline Feb & 1.79 & -16.67 \\
\hline Mar & 1.87 & -14.54 \\
\hline Apr & 1.79 & -16.12 \\
\hline May & 1.77 & -13.78 \\
\hline Jun & 2.68 & -23.09 \\
\hline Jul & 2.71 & -29.11 \\
\hline Aug & 2.57 & -17.90 \\
\hline Sep & 2.29 & -15.23 \\
\hline
\end{tabular}

These trends were applied to the 50 synthetic timeseries and were introduced in the model. Final results concern the mean monthly difference in the basic parameters between the base run scenario and the mean results of the 50 timeseries for the climatic scenario.

\section{B. GIS-based multi-criteria analysis for hydrometeorological station network planning}

The monitoring of meteorological conditions constitutes basic infrastructure, necessary for the rational management of water resources (Baltas and Mimikou, 2009). The historical hydrological and meteorological data inadequacy was the driving force for the station network planning in Argolis. The current approach is a GIS-based multi-criteria analysis, which takes into consideration many geomorphological, technical, administrative and geometrical characteristics of the region, in order to suggest the optimal solution. A great number of layers are required; such as the digital elevation model (DEM), the spatial distribution of the road network, settlements, springs, boreholes and wells etc. The flowchart of the procedure is presented in Fig.4.

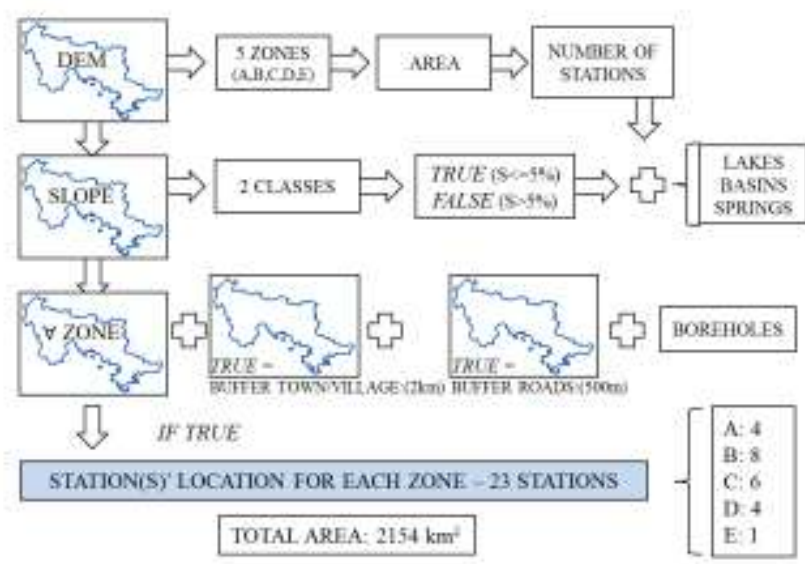

Figure 4. Flowchat of the multi-criteria analysis for station network planning

One of the most significant design criteria is the station density per elevation zone. The DEM was divided into five major elevation zones (Tab.4) after taking into account the guidelines of SOil and TErrain Digital Database, SOTER (Dobos et al., 2005).

TABLE 4. STATION DENSITY PER ELEVATION ZONE

\begin{tabular}{|c|c|}
\hline Zone & Station density \\
\hline $\mathrm{A}(0-200 \mathrm{~m})$ & 1 station per $600 \mathrm{~km}^{2}$ \\
\hline $\mathrm{B}(200-500 \mathrm{~m})$ & 1 station per $100 \mathrm{~km}^{2}$ \\
\hline $\mathrm{C}(500-800 \mathrm{~m})$ & 1 station per $75 \mathrm{~km}^{2}$ \\
\hline $\mathrm{D}(800-1200 \mathrm{~m})$ & 1 station per $50 \mathrm{~km}^{2}$ \\
\hline $\mathrm{E}(1200-2800 \mathrm{~m})$ & 1 station per $50 \mathrm{~km}^{2}$ \\
\hline
\end{tabular}

The density of the stations depends on the division of terrain into elevation zones, according to the guidelines of WMO (1983). WMO (1983) also suggests the meteorological stations be installed on terrain slope lower than 5\% and this criterion was taken into account in the present study. Different diameter buffer zones were created in order to detect areas close to water bodies (e.g. lakes), wells and boreholes, road network (for the easy access) and settlements. A further criterion was the representation of each land cover type, as well as the spatial uniformity of the network into the administrative boundary or the region.

\section{Results}

\section{A. Trends in hydrological parameters}

The results of the model implementation using the 50 timeseries were concerned as equivalent (probability 2\%) and their average monthly value was calculated. In this section, some of the results concerning the estimated monthly runoff and potential evapotranspiration are presented; these values are the most representative, including the affection of any probable climate change. Fig.5a shows the comparison between the mean monthly runoff (base run scenario) and the mean monthly climatic one (mean monthly estimated for the period 2016-2056). Fig.5b illustrates the monthly percentage change which seems to be more intensive in the spring and summer months, when the water needs maximize. 
Proc. of the Fourth International Conference on Advances in Civil, Structural and Environmental Engineering - ACSEE 2016. Copyright $\odot$ Institute of Research Engineers and Doctors. All rights reserved.

ISBN: 978-1-63248-114-6 doi: 10.15224/ 978-1-63248-114-6-65
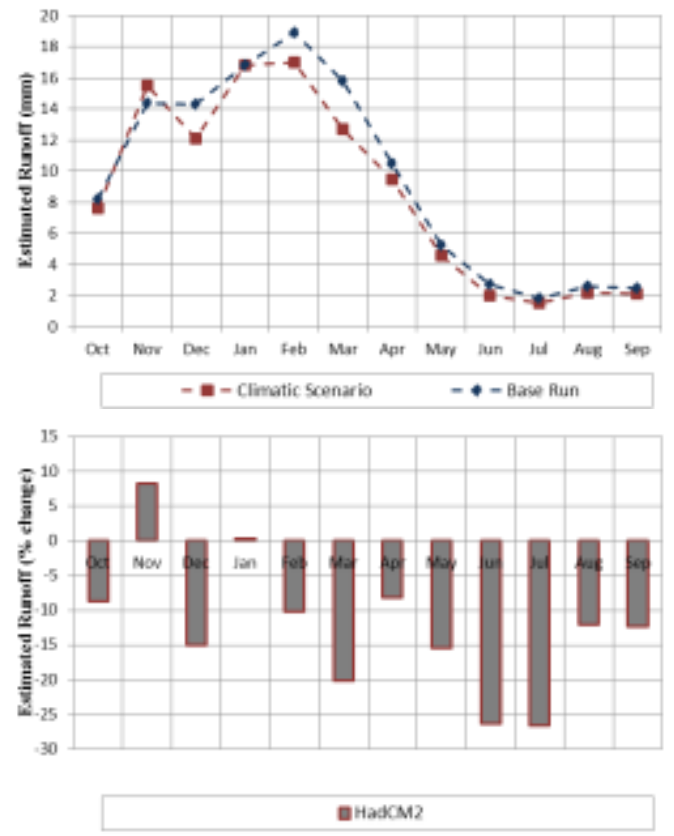

Figure 5. (a) Mean monthly runoff; Comparison between the base run and climatic scenario (b) Monthly percentage change

Because of the positive trends of temperature - according to the majority of the climatic scenarios - potential evapotranspiration shows a systematically increasing rate within the year. However, this increase seems to be higher in the transitional seasons (Fig.6a, Fig.6b).
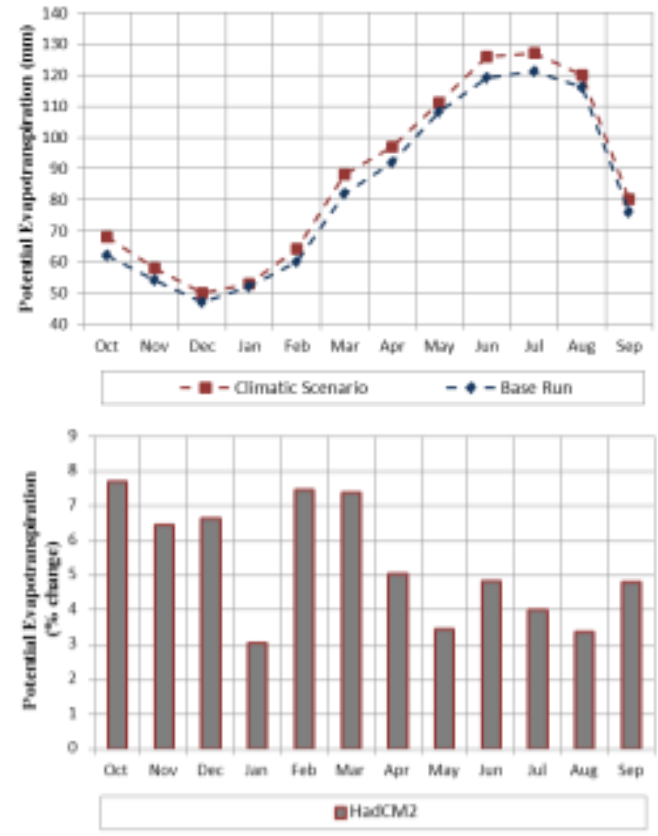

Figure 6. (a) Mean monthly potential evapotranspiration; Comparison between the base run and climatic scenario (b) Monthly percentage change

Concerning the annual change of runoff, its mean value is $8.93 \%$ and the annual fluctuation within the 40 years is shown in Fig.7.a. Particularly interesting is the comparison between the fluctuation in summer and winter months (Fig.7.b). Mean difference between the two scenarios is close to the annual one for the winter values and about $-21.06 \%$ for the summer runoff.
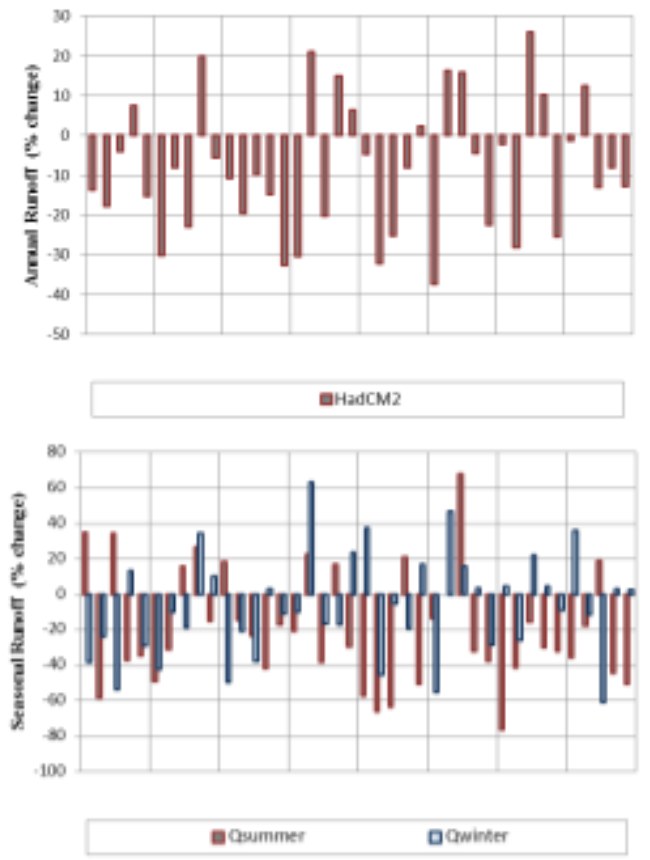

Figure 7. (a) Percentage change in annual runoff (b) Comparison between summer and winter runoff

Taking into account the negative annual and monthly mean values of runoff and precipitation, in combination with the increasing rate of precipitation and evapotranspiration, it seems that the already negative water balance is expected to deteriorate further. This reduction reaches $21 \%$ on summer months and in some years it exceeds the 50\%. Therefore, if these scenarios are confirmed, the study area will be highly deficient and water shortages will be more intensely and more often, considering the current management practices. The fact that, even without the impact of climate change, Argolis is characterized as of high risk from a quantitative and qualitative point of view, leads to the compulsory reconsideration of the current model of surface and groundwater resources exploitation.

\section{B. Management practices}

Taking into account the potential climate change or not, water supplies in Argolis are in danger. The current water resources management is almost absent and an optimum water management plan should be adopted. The basic idea includes an integrated change in the water management plan, with rationalization of the water prices and incentives modulation towards new agricultural patterns and practices. It also contains the improved operation of the current infrastructure; irrigation and water supply networks, monitoring networks. Additionally, new infrastructure development is needed, meaning the construction of water utilization works, reuse of degraded water and use of desalinated water. Educational and informative programs will be also beneficial for the local society. 
Proc. of the Fourth International Conference on Advances in Civil, Structural and Environmental Engineering - ACSEE 2016. Copyright $(\odot$ Institute of Research Engineers and Doctors. All rights reserved.

ISBN: 978-1-63248-114-6 doi: 10.15224/ 978-1-63248-114-6-65

\section{Station network planning}

The existence of homogenous historical meteorological and hydrological data is one of the main factors contributing the well-aimed water resources management. The absence of such data was the only drawback in the current study, and in the context of proposition of new management practices, a new station network was designed. The current network belongs to four difference national services (the National Meteorological Service, the Public Power Corporation, and the Ministries of Agriculture and Infrastructure). This aspect forms a spatially non-uniform network, with different types of data and periods of operation.

The analysis showed that although the $83 \%$ of the stations meets the accessibility criteria, the $70 \%$ of the stations are located in areas with slope greater than 5\%. The representation of high altitudes is also absent in the current network, a feature that complicates the proper estimation of precipitation. The comparison in the number of stations per elevation zone illustrates the nonexistence of any station in the maximum elevation zones $(D$ and $E$ ). Stations in Zone $A$ are denser that needed. The suggested network includes 23 hydrometeorological stations and two hydrometric in the Erasinos and Inahos basins (Argolikos plain). The special distribution of the suggested network is presented in the map of Fig.8. On occasions where it was possible, the existing stations were maintained; finally four stations are maintained.

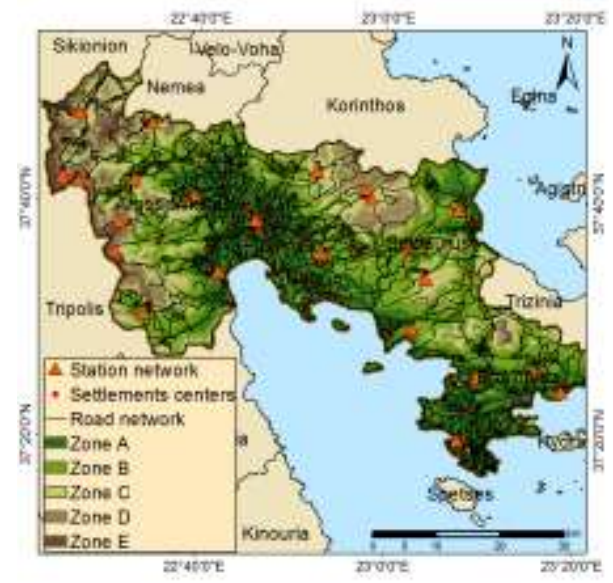

Figure 8 . The proposed station network with partial use of the existing one

\section{Conclusions}

This study is an attempt to assess the impact of climate change on water resources of Argolis, using a monthly water balance model, concerning the HadCM2 scenario for the period 2016 2056.

In respect to the impact of climate change on the hydrological cycle of the region, the main findings are the following:

- The mean monthly runoff presents downward trends throughout the year, which are less significant in autumn and early winter months.

- The increase of the mean monthly temperature consequently results in an increase in the monthly evapotranspiration
- The average values of runoff and rainfall present negative trends.

- The decrease for summer months is estimated in average 8\%, while there many cases in the examined period where the reduction expected is $-50 \%$ compared with today water availability levels. Water scarcity problems are mainly affect areas due to socioeconomic reasons, despite the fact that there is not existing any extreme shortage in the natural water resources.

- Concerning the current station network assessment, the majority of the current stations are located in unsuitable locations and present significant lacks of data. The redesign of the network seems to be required in the context of the integrated local water resources management.

\section{Acknowledgment}

This research is a part of the project entitled "Optimization of Water resources management in Argolis, under uncertain climate conditions" Region. The authors acknowledge the Hellenic National Meteorological Service, the Public Power Corporation, the Ministry of Agriculture, the Ministry of Infrastructure, the Municipality of Argos-Mikines and the National Cadastre and Mapping Agency for the provision of the necessary data.

\section{References}

[1] Baltas, E.A. and Mimikou, M.A., 2009. GIS-based optimisation of the hydrometeorological network in Greece. International Journal of Digital Earth, 2(2), pp.171-185.

[2] Biswas, A. K., 2004 "Integrated water resources management: a reassessment: a water forum contribution." Water international 29.2: 248-256.

[3] Dobos, E., Daroussin, J. and Montanarella, L., 2005. A SRTM basedprocedure to delineate SOTER Terrain Units on 1: $1 \mathrm{M}$ and 1: 5M scales. European Commission Report, EUR, 21571.

[4] Gleick, P. H. "Water in crisis: paths to sustainable water use." Ecological applications 8.3: 571-579.

[5] Mimikou, M.A., Baltas, E., Varanou, E. and Pantazis, K., 2000. Regional impacts of climate change on water resources quantity and quality indicators. Journal of Hydrology, 234(1), pp.95-109.

[6] Mimikou, M., Kouvopoulos, Y., Cavadias, G. and Vayianos, N., 1991. Regional hydrological effects of climate change. Journal of Hydrology, 123(1), pp.119-146.

[7] Papageorgiou, A., D. M. Voicilas, and Tudor, M., 2007. "Greece in the European Union and the Agro-food Industry: Spatial Reorganizations." Rural Areas and Development 5.

[8] Singh, Vijay P., and Frevert, D. K., 2002. Mathematical models of large watershed hydrology. Water Resources Publication.

[9] World Meteorological Organization (WMO), 1983. Guide to Meteorological Instruments and Methods of Observation. WMO-No.8, 5th ed., Chapter 7, Geneva, Switzerland: WMO. 